\title{
SYNTHESIS AND CHARACTERIZATION OF MANGANESE- COBALT SOLID SOLUTIONS PREPARED AT LOW TEMPERATURE
}

\author{
EDMUNDO RIOS ${ }^{1}$, PATRICIO LARA ${ }^{2}$ DANIEL SERAFINI ${ }^{2,3}$, AMBROSIO RESTOVIC ${ }^{4}$ AND \\ JUAN LUIS GAUTIER ${ }^{1, *}$
}

\begin{abstract}
${ }^{1}$ Laboratorio de Fisicoquímica y Electroquímica de Sólidos. Departamento de Química de los Materiales, Facultad de Química y Biología, Universidad de Santiago de Chile, Av. L. B. O'Higgins 3363, Santiago, Chile.

${ }^{2}$ Departamento de Física, Facultad de Ciencia, Universidad de Santiago de Chile, Av. Ecuador 3493. Santiago, Chile. ${ }^{3}$ Centro para la Investigación Interdisciplinaria Avanzada en Materiales, CIMAT, Av. Blanco Encalada 2008, Santiago, Chile. ${ }^{4}$ Departamento de Química, Facultad de Ciencias Básicas, Universidad de Antofagasta, Campus Coloso, Antofagasta, Chile. (Received: November 17, 2009 - Accepted: January 26, 2010)
\end{abstract}

\begin{abstract}
Two extreme compositions of the manganese-cobalt oxide system $\mathrm{Mn} \mathrm{Co}_{3-\mathrm{O}} \mathrm{O}_{4}$ namely $\mathrm{Co}_{3} \mathrm{O}_{4}(\mathrm{x}=0)$ and $\mathrm{MnCo}_{2} \mathrm{O}_{4}(\mathrm{x}=1)$ were prepared in powder form at low temperature by thermal decomposition of nitrates in air. The synthesis was conducted at $150^{\circ} \mathrm{C}$. The oxides obtained were characterized by different techniques such as X-ray diffraction (XRD), scanning electron microscopy (SEM), surface area determination using the Brunauer-Emmett-Teller (BET) method, thermogravimetric analyses (TGA) and oxidation power (OP). XRD analysis reveals that the oxides crystallize in a cubic spinel-type structure with a unit cell parameter $\left(\mathrm{a}_{\mathrm{o}}\right)$ that increases as cobalt is replaced by manganese. The $\mathrm{MnCo}_{2} \mathrm{O}_{4}$ showed $70 \mathrm{~m}^{2} \mathrm{~g}^{-1}$ and $13 \mathrm{~nm}$ of specific surface area and crystallite size respectively. The crystallite was bigger $(20 \mathrm{~nm})$ when cobalt-manganese oxide is prepared as a thin film. Both compounds exhibited nanometric size. The cationic distributions proposed for both oxides on the basis of the physicochemical characterization results showed an excellent agreement with those obtained from the XRD data refinement performed using the Rietveld method.
\end{abstract}

Keywords: Manganese cobalt oxide, Mixed oxides, Spinels, Solid Solution, Manganese-cobalt distribution

\section{INTRODUCTION}

Spinel type oxides from transition metals, particularly the manganesecobalt oxide family, are interesting systems because of their potential for a variety of applications in the conversion of energy ${ }^{1,2}$. Many different synthetic routes have been attempted to prepare $\mathrm{Mn} \mathrm{Co}_{3} \mathrm{O}_{4}$ oxides in powder form ${ }^{3}$. The commonest method for the preparation of these spinels has been the thermal decomposition of nitrate precursors at different temperatures. From a practical point of view, the search is oriented to obtain the highest specific area in addition to the highest intrinsic activity. Mixed valence oxides have rather low specific surface areas, mainly when they are prepared at high temperature by conventional ceramic methods or decomposition of dry salts routes. However, they may reach higher specific surface areas when they are obtained at lower temperatures by thermal decomposition of suitable precursors ${ }^{4}$.

In the thermal process of powder preparation, the higher specific areas are obtained at lower temperatures ${ }^{5}$. On the other hand, when the powders are synthesized at low temperatures from aqueous solutions, water molecules and $\mathrm{OH}$ groups end up attached to the oxide structure ${ }^{4}$. Besides, thermally formed oxides are as a rule non-stoichiometric. A common feature is that non-stoichiometry decreases when the calcination temperature increases, thus paralleling the decrease in surface area ${ }^{6}$. The solid-state properties of the two extreme compositions of a series of mixed oxides $\mathrm{Mn}_{\mathrm{x}} \mathrm{Co}_{3-\mathrm{x}} \mathrm{O}_{4}(0 \leq$ $\leq \mathrm{x} £ 1$ ), i.e, the spinel oxides of cobalt $\mathrm{Co}_{3} \mathrm{O}_{4}(\mathrm{x}=0)$ and of manganese an $\mathrm{d}$ cobalt $\mathrm{MnCo}_{2} \mathrm{O}_{4}(\mathrm{x}=1)$, have been more intensively investigated than the intermediate compositions (with $\mathrm{x}$ varying from $\mathrm{x}=0$ to $\mathrm{x}=1$ and with $\Delta \mathrm{x}=$ $0.25)$.

The formula of a binary spinel oxide is $\mathrm{A}\left[\mathrm{B}_{2}\right] \mathrm{O}_{4}$ in which $\mathrm{A}$ is a cation tetrahedrically coordinated with the oxygen while the $\mathrm{B}$ cation is octahedrically coordinated with the oxygen. Each cubic unit cell contains 8 formal units $A\left[\mathrm{~B}_{2}\right]$ $\mathrm{O}_{4}$, that is to say it corresponds to $\mathrm{A}_{8} \mathrm{~B}_{16} \mathrm{O}_{32}$. Spinels are usually classified as normal, inverted or random ${ }^{2}$.

Owing to the multiple oxidation states that the mixed oxides formed in the Mn-Co-O system can adopt, the determination of the oxidation states and cation distributions among both the tetrahedral and octahedral sublattices of the spinel structure are not simple tasks ${ }^{7-9}$. There is overwhelming evidence in the literature that the distribution of the cationic oxidation states among the different crystallographic sites greatly depends on the preparation conditions and also determines the textural and morphological characteristics of the powder oxides ${ }^{10}$

Early investigations by Wickham and Croft ${ }^{11}$ and Naka et al. ${ }^{12}$ have shown that a single stable phase of the cubic manganese-cobalt spinel exists at $1000^{\circ} \mathrm{C}$ only for the $0 \leq \mathrm{x} \leq 1.3$ composition range. It is now widely accepted in the literature ${ }^{13-19}$ that $\mathrm{Co}_{3} \mathrm{O}_{4}$ exhibits a normal cationic distribution, with low spin $\mathrm{Co}^{3+}$ in octahedral sites and high spin $\mathrm{Co}^{2+}$ in tetrahedral sites: $\mathrm{Co}^{2+}\left[\mathrm{Co}^{\text {III }} \mathrm{Co}^{\text {III }}\right] \mathrm{O}_{4}$. In contrast, the cationic distribution of $\mathrm{MnCo}_{2} \mathrm{O}_{4}$ is not well established. Several cationic distributions have been proposed in stoichiometric $\mathrm{MnCo}_{2} \mathrm{O}_{4}$ and non-stoichiometric $\mathrm{Mn}_{\mathrm{x}} \mathrm{Co}_{3-\mathrm{x}} \mathrm{O}_{4+\mathrm{d}}$ oxides on the basis of (i) electrical conductivity ${ }^{10}: \mathrm{Co}^{2+}\left[\mathrm{Co}^{2+} \mathrm{Mn}^{4+}\right] \mathrm{O}_{4}$ or $\mathrm{Co}^{3+}\left[\mathrm{Co}^{3+} \mathrm{Mn}^{2+}\right] \mathrm{O}_{4}$, ii) magnetism: $\mathrm{Co}^{2+}\left[\mathrm{Co}_{2-\mathrm{x}}^{3+} \mathrm{Mn}_{\mathrm{x}}^{3+}\right] \mathrm{O}_{4}$ by Wickham and Croft ${ }^{11}$ and $\mathrm{Co}^{2+}\left[\mathrm{Co}^{2+} \mathrm{Mn}^{4+} \mathrm{O}_{4}\right.$ by Blasse ${ }^{20}$, and iii) neutron diffraction and magnetism measurements: $\mathrm{Co}^{2+}\left[\mathrm{Co}_{2-\mathrm{x}}^{3+} \mathrm{Mn}_{\mathrm{x}}^{3+}\right] \mathrm{O}_{4}$ by Boucher et al. ${ }^{21} \cdot \mathrm{Mn}_{\mathrm{x}} \mathrm{Co}_{3-}$ ${ }_{x} \mathrm{O}_{4}$ oxides are commonly described as being inverse spinels in which the manganese cations show preference for octahedral sites. Studies of the surface composition of $\mathrm{MnCo}_{2} \mathrm{O}_{4}$ by XPS have shown that the Co is present as $\mathrm{Co}^{2+}$ and $\mathrm{Co}^{3+}$ while $\mathrm{Mn}$ is mainly present as $\mathrm{Mn}^{3+}$ ions ${ }^{22}$. Ravindranathan et al. ${ }^{23}$ reported on the synthesis of $\mathrm{MnCo}_{2} \mathrm{O}_{4}$ from its organic precursor decomposition below $250^{\circ} \mathrm{C}$. Yamamoto et al. ${ }^{24}$ used neutron diffraction technique to study the oxide $\mathrm{MnCo}_{2} \mathrm{O}_{4}$ synthesised by a wet procedure at $80^{\circ} \mathrm{C}$, and have proposed $\mathrm{Mn}_{1-\mathrm{x}} \mathrm{Co}_{\mathrm{x}}\left[\mathrm{Mn}_{\mathrm{x}} \mathrm{Co}_{2-\mathrm{x}}\right] \mathrm{O}_{4}$ as the atomic distribution, where $\mathrm{x}$ is the inversion parameter. On the basis of chemical analysis, DRX, TGA, DTA and oxidation power measurements, Gautier, Fuentealba and Cabezas ${ }^{25}$ proposed a global formulae and ionic stoichiometry of $\mathrm{Mn}_{\mathrm{x}} \mathrm{Co}_{3-\mathrm{x}} \mathrm{O}_{4}(1 \geq \mathrm{x} \geq 0.25)$ prepared at $400^{\circ} \mathrm{C}$.

Depending on the preparation method and the calcination temperature, Gautier et al. have suggested the cationic distributions: $\mathrm{Co}^{2+}\left[\mathrm{Co}^{3+} \mathrm{Mn}_{0.35}^{2+} \mathrm{Mn}_{0.29}^{+3+} \mathrm{Mn}_{0.36}^{4+}\right] \mathrm{O}_{4} \quad{ }^{26}$ and $\mathrm{Co}^{2+}\left[\mathrm{Co}_{0.95}^{3+} \mathrm{Mn}_{0.015}^{2+} \mathrm{Mn}_{0.50}^{3+}\right.$ $\left.\mathrm{Mn}^{4+}{ }_{0.485}{ }_{0.05}\right] \mathrm{O}_{4}{ }^{27}$. The occurrence of $\mathrm{Mn}^{4+}$ cations in octahedral sites has been again considered by Jabry, Rousset and Lagrange ${ }^{28}$ from X-ray and electrical conductivity measurements: $\mathrm{Co}^{2+}\left[\mathrm{Co}_{\mathrm{x}}^{2+} \mathrm{Co}_{2(1-x)}^{3+} \mathrm{Mn}_{\mathrm{x}}^{4+}\right] \mathrm{O}_{4}$. Ríos et al. ${ }^{1}$ have prepared by thermal decomposition at $400^{\circ} \mathrm{C}$ of nitrates salts the entire series $\mathrm{Mn}_{\mathrm{x}} \mathrm{Co}_{3-\mathrm{x}} \mathrm{O}_{4}(0 \leq \mathrm{x} \leq 1)$ and proposed the corresponding cationic distributions. In the recent past we have undertaken the study of the title compound by spray pyrolysis at $150^{\circ} \mathrm{C}$ of the two extreme compositions $\mathrm{Co}_{3} \mathrm{O}_{4}$ and $\mathrm{MnCo}_{2} \mathrm{O}_{4}$, but were unable to obtain cationic distribution measurements due to material paucity ${ }^{5} \cdot \mathrm{Co}_{3} \mathrm{O}_{4}$ was prepared by a sol-gel process at $300^{\circ} \mathrm{C}{ }^{29}$ with large 
specific area $\left(27 \mathrm{~m}^{2} \mathrm{~g}^{-1}\right)$ while De Vidales et al. ${ }^{4}$ have prepared $\mathrm{MnCo}_{2} \mathrm{O}_{4}$ by a sol-gel route at $80^{\circ} \mathrm{C}$ with larger specific surface area. The temperature at which the $\mathrm{Co}_{3} \mathrm{O}_{4}$ spinel oxide is formed changes with the heating rate. Pope et al. ${ }^{30}$ observed that the decomposition was already completed at $200^{\circ} \mathrm{C}$, when the heating rate was lowered, while Garavaglia et al. ${ }^{31}$ reported that at sufficiently long times $\mathrm{Co}_{3} \mathrm{O}_{4}$ is formed at $150^{\circ} \mathrm{C}(24 \mathrm{~h})$.

In this work, we report the successful preparation at low temperature, on the two extreme compositions of $\mathrm{Mn}_{\mathrm{x}} \mathrm{Co}_{3 \mathrm{x}} \mathrm{O}_{4}$ material, $\mathrm{Co}_{3} \mathrm{O}_{4}(\mathrm{x}=0)$ and $\mathrm{MnCo}_{2} \mathrm{O}_{4}$ $(\mathrm{x}=1)$, using a thermal decomposition procedure with proper salt precursors. A series of physicochemical measurements have enabled us to propose the cationic distributions which have been confirmed by the application of the Rietveld structural analysis method. A further crystallographic study for the rest of the oxides family, namely for $\mathrm{x}=0.25,0.5$ and 0.75 , and a study of the effects of solid state properties of the entire series of the spinel-type $\mathrm{Mn}_{\mathrm{x}} \mathrm{Co}_{3-}$ $\mathrm{O}_{4}(0 \leq \mathrm{x} \leq 1)$ compounds on their electrocatalytic properties, are currently in progress.

\section{EXPERIMENTAL}

Preparation of $\mathrm{Mn}_{x} \mathrm{Co}_{3-x} \mathrm{O}_{4}$ oxides

The chemical synthesis of the polycrystalline compounds $\mathrm{Mn}_{\mathrm{x}} \mathrm{Co}_{3-\mathrm{x}} \mathrm{O}_{4}(\mathrm{x}$

$=0$ and 1.0) were conducted by thermal decomposition of nitrate solutions.

$\mathrm{Co}_{3} \mathrm{O}_{4}$ synthesis

$\mathrm{Co}\left(\mathrm{NO}_{3}\right)_{2} \cdot 6 \mathrm{H}_{2} \mathrm{O}$ (Fluka p.a. ref. 60833) was allowed to dissolve in its crystallization water by gradually heating it up to $100^{\circ} \mathrm{C}$. The solution was then evaporated and the residual solid nitrate was further decomposed in air at $150^{\circ} \mathrm{C}$.

$\mathrm{MnCo}_{2} \mathrm{O}_{4}$ synthesis

The aqueous precursor solutions were made up of cobalt and manganese nitrate salts (analytical grade) $\mathrm{Co}\left(\mathrm{NO}_{3}\right)_{2} \cdot 6 \mathrm{H}_{2} \mathrm{O}$ (Fluka p.a. ref. 60833) and $\mathrm{Mn}\left(\mathrm{NO}_{3}\right)_{2} \cdot 4 \mathrm{H}_{2} \mathrm{O}$ (Merck p.a. ref. 5942), whose concentrations were 0.100 and $0.0947 \mathrm{M}$, respectively. To avoid metal hydroxide precipitation, these solutions were slightly acidified with $1 \mathrm{~mL}$ of concentrated $\mathrm{HNO}_{3}$ (Merck p.a.) per liter. The expected stoichiometry was obtained by mixing the required amounts of the starting solutions to yield the desired concentration. The overall concentration of the mixed solutions was $0.08 \mathrm{M}$.

The above mentioned cobalt nitrate and the corresponding mixture were separately heated slowly on a sand bath to evaporate the water until a dry solid residue was obtained. Further decomposition in air at $150^{\circ} \mathrm{C}$ was conducted until complete cessation of the red-coloured nitrous vapours $\left(\mathrm{NO}_{\mathrm{x}}\right)$, coming from the nitrates decomposition. The residual powder was carefully ground, sieved (400 mesh) and then calcined inside a tubular furnace for 24 hours in an alumina crucible at $150^{\circ} \mathrm{C}$ in air. After cooling to room temperature (RT), the resulting powder was again submitted to prolonged cycles of grinding and reheated at the same temperature, to ensure the total decomposition of the oxides. Total calcination time was 5 days. All the final products were black in colour. Once the binary oxides formation was accomplished the samples were stored in a desiccator under vacuum.

Chemical analysis

The accurate cationic concentrations of Co and $\mathrm{Mn}$ both in the mother liquors and in the final products were controlled by Induced Coupled PlasmaOptical Emission (ICP-OE) Spectroscopy, using an Optima 2000 DV PerkinElmer apparatus, not only for checking their actual rate, but also because there is always some doubt about the composition of manganese nitrate due to the hygroscopic character of the starting salt. For these classical analyses, the samples were dissolved in acidic media and then the metallic cation ratios were determined using $\mathrm{Mn}$ and Co standards from Perkin-Elmer $\left(1 \mathrm{mg} \mathrm{mL}^{-1}\right)$. The cationic $\mathrm{Co} / \mathrm{Mn}$ ratios present in solution were satisfactorily retained in the oxide powders. Within experimental error $( \pm 2 \%)$, the composition of all the compounds were in good agreement with the expected ones.

$X$-ray diffraction

Crystallographic structure and purity of the samples were carried out by X-ray powder diffraction (XRD), using a Siemens D500 diffractometer at RT employing a $\mathrm{Cu}$ anode $\mathrm{K} \alpha_{1}(\lambda=0.154060 \mathrm{~nm})$ and $\mathrm{K} \alpha_{2}(\lambda=0.1540431 \mathrm{~nm})$ in Bragg-Brentano geometry. The voltage and intensity current were set to $40 \mathrm{kV}$ and $30 \mathrm{~mA}$, respectively. The data were collected in steps of $0.02^{\circ}(2 \theta)$ with a fixed-time counting of $5 \mathrm{~s}$. Profiles were measured in the range $10^{\circ}$ to $110^{\circ}(2 \theta)$ since no detectable peaks were observed beyond these values. The refinement of X-ray diffraction results was performed using the Rietveld's profile analysis method with the Fullprof Suite program ${ }^{32}$.

SEM analysis

In order to estimate the average aggregate size and crystallinity degree of the oxides, the microstructures of the powders were examined by scanning electron microscopy (SEM) using a JEOL apparatus (JSM 5410). The details of surface morphology were studied at magnifications of up to $5000 \mathrm{X}$ by scanning electron microscopy.

Thermogravimetric analysis

The thermogravimetric analysis (TGA) and differential scanning calorimetry (DSC) curves were obtained using a TA Instruments SDT 2960 under a dry static air atmosphere. About a $40 \mathrm{mg}$ sample was used in each run, and $\alpha-\mathrm{Al}_{2} \mathrm{O}_{3}$ was the inert reference material. The material was heated from RT

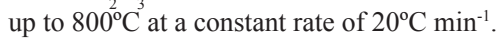

Specific surface areas

The specific surface areas of the oxides were measured by the BrunauerEmmet and Teller (BET) method. Nitrogen physisorption measurements of the fresh samples were performed in a standard Sorptometer Micromeritics ASAP 2010.

\section{Oxidation power $q(x)$.}

The oxidation power $\mathrm{q}(\mathrm{x})$ of the oxide can be defined as the degree of oxidation power of the spinel with regard to a soft reduction agent ${ }^{33}$. This parameter (eq $\mathrm{mol}^{-1}$ ) was determined by chemical reduction of the oxide cations $\mathrm{M}^{\mathrm{n}}$ with $\mathrm{n} \geq 3$ until oxidation state 2 was reached using a mild reducing agent, such as vanadyl sulphate sulphuric solution $\left(1 \mathrm{~N} \mathrm{VOSO}_{4}\right)$ according to the reaction:

$$
\mathrm{M}^{\mathrm{n}+}(\mathrm{s})+(\mathrm{n}-2) \mathrm{VO}^{+2}(\mathrm{aq})+3(\mathrm{n}-2) \mathrm{H}_{2} \mathrm{O} \rightarrow \mathrm{M}^{+2}(\mathrm{aq})+(\mathrm{n}-2) \mathrm{V}(\mathrm{OH})_{4}^{+}(\mathrm{aq})+2(\mathrm{n}-
$$
2) $\mathrm{H}^{+}(\mathrm{aq})$

This measurement reflects the quantity of electrons per mole of $\left(\mathrm{Mn}_{\mathrm{x}} \mathrm{Co}_{3-\mathrm{x}}\right)^{8+}$ with $\mathrm{q}(\mathrm{x})>2$ necessary to level all oxidation states to 2 . The oxide samples (50 mg approximately) were dissolved in a known excess amount $(50 \mathrm{~mL})$ of $\mathrm{VOSO}_{4}$ (Merck p.a.) in sulfuric acid solution (to avoid cationic hydrolysis). Because of the extended periods of digestion required to dissolve the samples, the mixture was heated at $90^{\circ} \mathrm{C}$ for 48 hours. After complete dissolution of the oxide, the unreacted $\mathrm{VOSO}_{4}$ was potentiometrically titrated with $1 \mathrm{~N} \mathrm{KMnO}_{4}$ solution, which had been previously standardized with oxalate solution according to McBride's method ${ }^{34}$. The oxidation power was calculated according to the equation:

$$
\mathrm{q}(\mathrm{x})=\left(\mathrm{V}_{\mathrm{VO}} \mathrm{N}_{\mathrm{VO}}-\mathrm{V}_{\mathrm{K}} \mathrm{N}_{\mathrm{K}}\right) \mathrm{M}_{\mathrm{ox}} / \mathrm{m}_{\mathrm{ox}}
$$

where $\mathrm{V}_{\mathrm{VO}}$ and $\mathrm{N}_{\mathrm{VO}}$ and $\mathrm{V}_{\mathrm{K}}$ and $\mathrm{N}_{\mathrm{K}}$ are the volume and concentration of the $\mathrm{VOSO}_{4}$ solution and the $\mathrm{KMnO}_{4}$ solution, respectively, $\mathrm{M}_{\text {ox }}$ and $\mathrm{m}_{\mathrm{ox}}$ corresponding to the molar mass and weight of the oxide. Each determination was made at least three times. The overall standard deviation was \pm 0.02 .

A cationic distribution derived from the X-ray diffraction pattern and the oxidation power were computed using the method of Poix ${ }^{35}$ based on the best fit with the equation: $\mathrm{a}=2.0995 \mathrm{a}+\left[5.18182 \mathrm{~b}^{2}-1.4107 \alpha^{2}\right]^{1 / 2}$ in which $\alpha=$ $\sum x_{i}\left(M_{i}-O\right)_{T d} / a x_{i}$ and $\beta=a ̊ x_{i}\left(M_{i}-O\right)_{O h} / a x_{i}$, with $x_{i}$ being the stoichiometric coefficient of the cation $\mathrm{M}_{\mathrm{i}}$ and $\mathrm{M}_{\mathrm{i}}-\mathrm{O}$ the cation oxygen distances in the tetrahedral $(\mathrm{Td})$ and octahedral $(\mathrm{Oh})$ sites according to the Shannon and Prewitt data ${ }^{36}$ and, considering the energetic preference of a cation for either site, according to Paul and Basu ${ }^{37}$. The presence of the $\mathrm{Mn}^{3+}$ and $\mathrm{Mn}^{4+}$ ions in octahedral sites and the occupancy of tetrahedral sites by the $\mathrm{Co}^{2+}$ and $\mathrm{Mn}^{2+}$ ions for the cobalt-manganese spinel have been already established in the literature ${ }^{38-40}$.

\section{RESULTS AND DISCUSSION}

3.1. Structural properties of $\mathrm{Co}_{3} \mathrm{O}_{4}$ and $\mathrm{MnCo}_{2} \mathrm{O}_{4}$ oxides. 


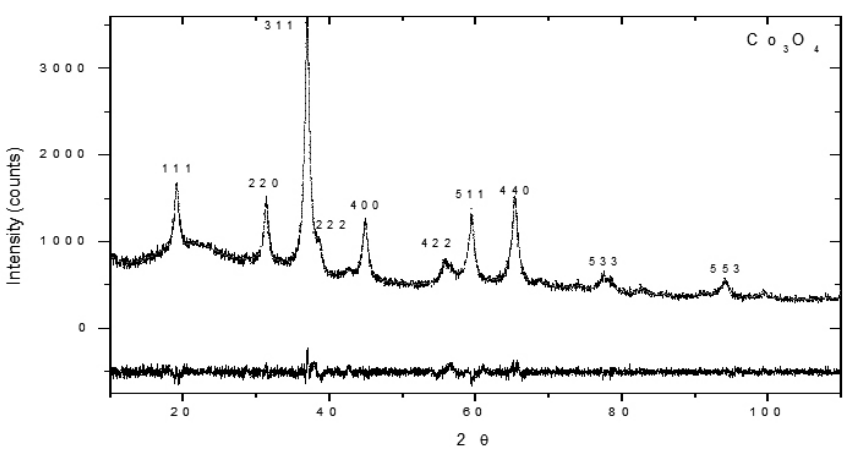

Figure. 1A. Rietveld refinement plots for $\mathrm{Co}_{3} \mathrm{O}_{4}$. The experimental and calculated intensity data are plotted as dotted and solid lines respectively and the difference $\left(\mathrm{I}_{\text {exp }}-\mathrm{I}_{\text {cal }}\right)$ below.

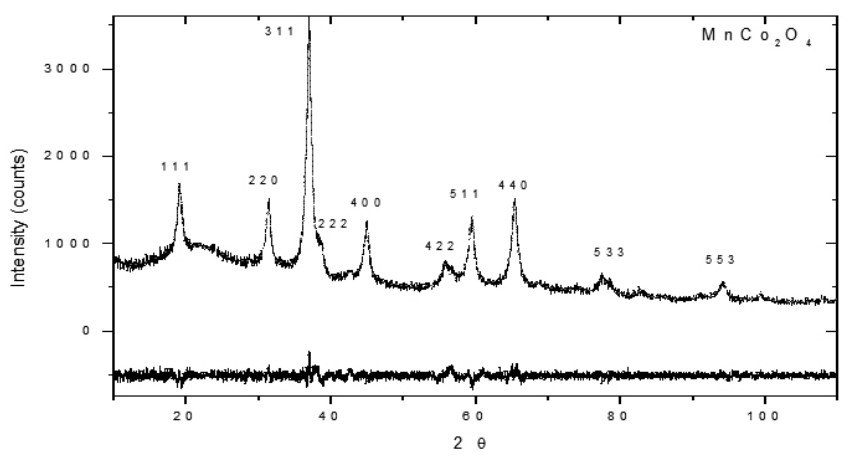

Figure. 1B. Rietveld refinement plots for $\mathrm{MnCo}_{2} \mathrm{O}_{4}$. The experimental and calculated intensity data are plotted as dotted and solid lines respectively and the difference $\left(I_{\text {exp }}-I_{\text {cal }}\right)$ below.

Figures $1 \mathrm{~A}$ and $1 \mathrm{~B}$ show the $\mathrm{X}$-ray diffraction patterns of the $\mathrm{Co}_{3} \mathrm{O}_{4}$ and $\mathrm{MnCo}_{2} \mathrm{O}_{4}$ phases respectively. Even if the crystalline state is not better defined due to the low temperature of synthesis ${ }^{41}$, Rietveld analysis shows single phases corresponding to the expected compounds which crystallize in the face centered cubic system spinel type, spatial group $o_{h}^{7}(\mathrm{Fd} 3 \mathrm{~m})$. All the main peaks (indicated by their hkl indices) could be indexed by comparison with the diffraction patterns of $\mathrm{Co}_{3} \mathrm{O}_{4}$ and $\mathrm{MnCo}_{2} \mathrm{O}_{4}$. Both the position and the relative intensities of the diffraction lines were found to be in good agreement with the ASTM X-ray powder data files JCPDS-ICDD for $\mathrm{Co}_{3} \mathrm{O}_{4}$ and $\mathrm{MnCo}_{2} \mathrm{O}_{4}$, thus showing that a single phase of each component was present. A remarkable common feature of the X-ray spectra of both spinel oxides prepared at such a low temperature was the good definition of the diffraction lines. The mayor peak in both XRD profiles was found to correspond to the (311) crystallographic plane. The $\mathrm{Co}_{3} \mathrm{O}_{4}$ lattice constant $\left(\mathrm{a}_{\mathrm{o}}=0.8079 \mathrm{~nm}\right)$ shows an acceptable good agreement with the 8-418 ASTM file value of $0.8084 \mathrm{~nm}$ for a product prepared at $8500^{\circ} \mathrm{C}$. For $\mathrm{MnCo}_{2} \mathrm{O}_{4}$ a more pronounced discrepancy was observed $\left(\mathrm{a}_{\mathrm{o}}=\right.$ $0.8089 \mathrm{~nm}$ ) with the 23-1237 ASTM file value of $0.8269 \mathrm{~nm}$, not only due to differences between the preparation method (ceramic procedure), but also due to the temperature of the preparation $\left(720^{\circ} \mathrm{C}\right)$. This higher variation for $\mathrm{MnCo}_{2} \mathrm{O}_{4}$ suggests the presence of cations with a high oxidation state that must be distributed in a smaller size cell and a cationic stoichiometric deficiency should not be ruled out.

The diffractograms in Fig. 1 show a loss of crystallinity going from $\mathrm{Co}_{3} \mathrm{O}_{4}$ to $\mathrm{MnCo}_{2} \mathrm{O}_{4}$. Broader diffraction peaks at the same positions were observed indicating that $\mathrm{MnCo}_{2} \mathrm{O}_{4}(13 \mathrm{~nm})$ have a smaller crystallite size than $\mathrm{Co}_{3} \mathrm{O}_{4}$ $(45 \mathrm{~nm})($ see Table I)
Table I. Structural and refinement parameters of $\mathrm{Mn}_{\mathrm{x}} \mathrm{Co}_{3-\mathrm{x}} \mathrm{O}_{4}(\mathrm{x}=0$ and 1).

\begin{tabular}{|c|c|c|c|c|}
\hline Compound & $\begin{array}{c}\text { Lattice } \\
\text { parameter } \\
\mathbf{a}_{\mathbf{0}} \pm \mathbf{0 . 0 0 0 3} / \mathbf{n m}\end{array}$ & $\mathbf{R}_{\text {Bragg }}$ & GOF & $\begin{array}{c}\text { Average } \\
\text { crystallite } \\
\text { size } / \mathbf{n m}\end{array}$ \\
\hline $\mathrm{Co}_{3} \mathrm{O}_{4}$ & $0.8078_{8}$ & 2.056 & 1.143 & 45 \\
\hline $\mathrm{MnCo}_{2} \mathrm{O}_{4}$ & $0.8089_{4}$ & 2.161 & 1.241 & 13 \\
\hline
\end{tabular}

The fractional coordinates of the atoms in the cell as well as the starting refinement were established on the basis of the model by Knop et al. ${ }^{18}$ for $\mathrm{Co}_{3} \mathrm{O}_{4}\left(\mathrm{a}_{\mathrm{o}}=0.80835 \mathrm{~nm}\right)$, which provides the best results for the fit. With this model the families of planes shown in Fig. 1 were indexed. The results of applying the structure refinement procedure to the experimentally determined intensities for the entire set of diffraction lines are shown in table I. This table includes the lattice parameter, the Bragg factor and the goodness of fit (GOF) that provides the refinement. Besides, it also shows the coherent diffraction size (crystallite) and the non-uniform micro deformation values obtained using the Wilson equation ${ }^{42}$ and full width at half maximum (FWHM) in the case of pseudo Voigt function of the peaks that are shown. The cubic cell parameter increases with an increase in manganese content, as expected. This result was interpreted as an effect of the substitution of Co-cations by larger Mn-cations ${ }^{43}$ as can seen in Table II. The decrease of the lattice parameter of the $\mathrm{Co}_{3} \mathrm{O}$ with respect to the starting model can be attributed to the low temperature of the preparation.

Table II. Effective ionic radii. hs = high spin, lh= low spin.

\begin{tabular}{|c|c|c|c|c|c|c|c|}
\hline Ion & $\begin{array}{c}\text { Coordi- } \\
\text { nation }\end{array}$ & $\begin{array}{c}\text { Spin } \\
\text { State }\end{array}$ & $\begin{array}{c}\text { Ionic } \\
\text { Radius/ } \\
\text { nm }\end{array}$ & Ion & $\begin{array}{c}\text { Coordi- } \\
\text { nation }\end{array}$ & $\begin{array}{c}\text { Spin } \\
\text { State }\end{array}$ & $\begin{array}{c}\text { Ionic } \\
\text { Radius/ } \\
\text { nm }\end{array}$ \\
\hline $\mathrm{Co}^{2+}$ & $\mathrm{IV}$ & $\mathrm{hs}$ & 0.058 & $\mathrm{Mn}^{2+}$ & $\mathrm{IV}$ & $\mathrm{hs}$ & 0.066 \\
\hline & $\mathrm{VI}$ & $\mathrm{ls}$ & 0.065 & & $\mathrm{VI}$ & $\mathrm{ls}$ & 0.067 \\
\hline & & $\mathrm{hs}$ & 0.0745 & & & $\mathrm{hs}$ & 0.083 \\
\hline $\mathrm{Co}^{3+}$ & $\mathrm{VI}$ & $\mathrm{ls}$ & 0.0545 & $\mathrm{Mn}^{3+}$ & $\mathrm{VI}$ & $\mathrm{ls}$ & 0.058 \\
\hline & & $\mathrm{hs}$ & 0.061 & & & $\mathrm{hs}$ & 0.0645 \\
\hline & & & & $\mathrm{Mn}^{4+}$ & $\mathrm{IV}$ & & 0.039 \\
\hline
\end{tabular}

The powders of the oxides present an average crystal size in the range of $13-45 \mathrm{~nm}$, confirming that the oxide particles were actually nanometric. The low crystal size can be explained by the low temperature used in the preparation of the oxides.

\section{SEM}

Figures $2 \mathrm{~A}$ and $2 \mathrm{~B}$ show SEM micrographs of the samples $\mathrm{Co}_{3} \mathrm{O}_{4}$ and $\mathrm{MnCo}_{2} \mathrm{O}_{4}$. The magnified images show differences in the morphology between the products. From a morphological point of view the particles of $\mathrm{Co}_{3} \mathrm{O}_{4}$ are agglomerated while $\mathrm{MnCo}_{2} \mathrm{O}_{4}$ shows particles geometrically defined (nearly trapezoidal crystallites). The average grain size of both samples measured from SEM micrographs lies in the range $1-8 \mathrm{~mm}$.

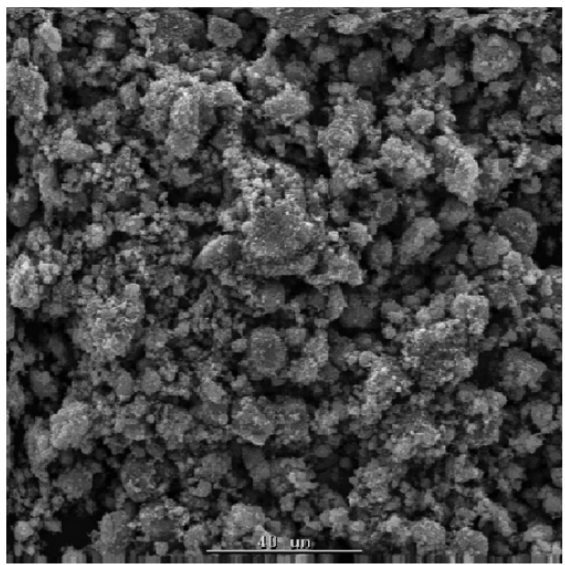

Figure 2A. SEM micrographs of the $\mathrm{Co}_{3} \mathrm{O}_{4}$ powder. $\mathrm{X}=5000$. 


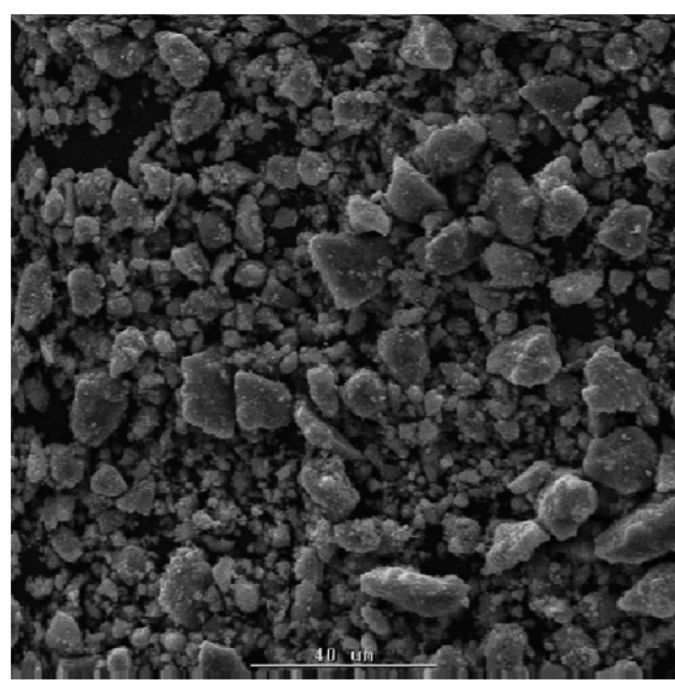

Figure 2B.SEM micrographs of the $\mathrm{MnCo}_{2} \mathrm{O}_{4}$ powder. $\mathrm{X}=5000$.

\section{Thermogravimetric studies}

The thermogravimetric analysis (TGA) in air of dried $\mathrm{Co}_{3} \mathrm{O}_{4}$ and $\mathrm{MnCo}_{2} \mathrm{O}_{4}$ powders are presented in Figure 3 and 4 respectively. Both TG curves show a thermal decomposition process involving several steps that begin at RT and finish near $600^{\circ} \mathrm{C}$. On the curves, mainly three regions of mass loss can be distinguished. The processes occurring during the course of heating should include: physisorbed water evolution, water from $\mathrm{OH}$ groups adsorbed onto the surface of the oxide particles ${ }^{44}$ and a progressive loss of the excess oxygen in the non-stoichiometric oxide ${ }^{31}$, namely $\mathrm{Co}_{3} \mathrm{O}_{4+\mathrm{d}}$ and $\mathrm{MnCo}_{2} \mathrm{O}_{4+\mathrm{d}}$. Gyrdasova et al. ${ }^{45}$ have prepared $\mathrm{MnCo}_{2} \mathrm{O}_{4}$ from manganese cobalt oxalate. They reported the formation of a cubic spinel phase at $200^{\circ} \mathrm{C}$. According to TG data the difference between the calculated and experimentally determined values of mass loss points to a higher oxygen content and consequently cationic deficiency. Further heating of $\mathrm{MnCo}_{2} \mathrm{O}_{4}$ at $700^{\circ} \mathrm{C}$ make lose oxygen and converts to the stoichiometric spinel $\mathrm{MnCo}_{2} \mathrm{O}_{4}$. At this temperature its lattice parameter is $\mathrm{a}_{\mathrm{o}}=0.8226 \mathrm{~nm}$. The increase in $\mathrm{a}_{\mathrm{o}}$ is likely due to the reduction of manganese or cobalt.

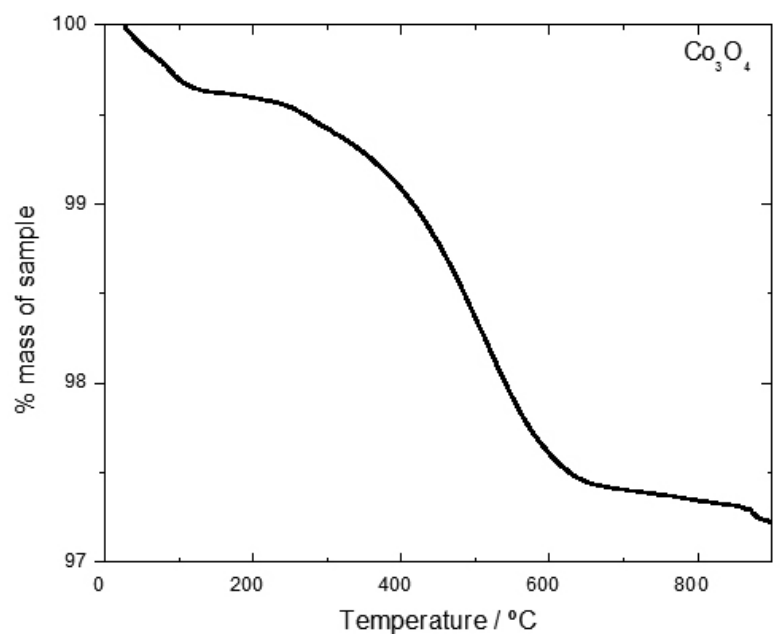

Figure 3. TGA curves recorded on $\mathrm{Co}_{3} \mathrm{O}_{4} \cdot \mathrm{v}=20^{\circ} \mathrm{C} \mathrm{min}^{-1}$, air atmosphere.

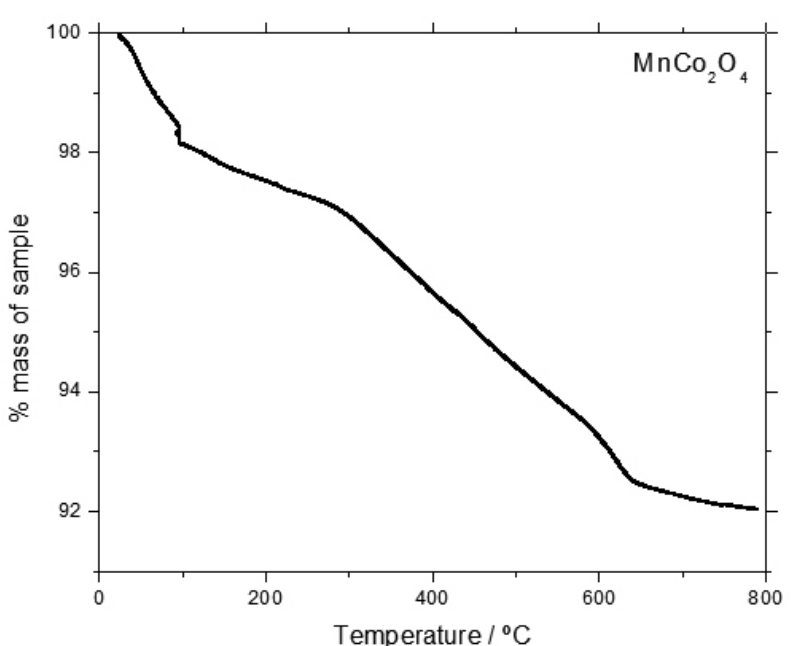

Figure 4. TGA curves recorded on $\mathrm{MnCo}_{2} \mathrm{O}_{4} \cdot \mathrm{v}=20^{\circ} \mathrm{C} \min ^{-1}$, air atmosphere.

\section{Specific surface areas}

The BET analysis performed on $\mathrm{MnCo}_{2} \mathrm{O}_{4}$ gave an average specific surface area of $70 \mathrm{~m}^{2} \mathrm{~g}^{-1}$. This value is higher than the one reported in the literature for $\mathrm{MnCo}_{2} \mathrm{O}_{4}$ prepared by a sol-gel process at $80^{\circ} \mathrm{C}$ with a surface area of $34 \mathrm{~m}^{2} \mathrm{~g}^{-1}$ ; the area increased to $44 \mathrm{~m}^{2} \mathrm{~g}^{-1}$ when annealing at $200^{\circ} \mathrm{C}^{4}$.

Oxidation power

The amount of equivalent per oxide mole, $\mathrm{q}(\mathrm{x})$, is higher for $\mathrm{MnCo}_{2} \mathrm{O}_{4}$. This suggests that the replacement of Co ions by Mn ions at the B octahedral sites would generate $\mathrm{Mn}$ ions with higher oxidation states.

\section{Cationic distributions}

A major challenge associated to the Mn-Co-O spinel-type systems is the determination of the metal oxidation states and cation distributions among the tetrahedral (labelled as A sites) and octahedral (B sites) sublattices of the spinel-related structure ${ }^{46}$. To put forward a tentative cation distribution for the compounds, the method of characteristic distances (invariants) developed by Poix ${ }^{35}$ has been used along with literature data. In Mn-Co spinels the most likely cationic distributions reported in the literature indicates predominantly the presence of $\mathrm{Co}^{2+}$ and $\mathrm{Mn}^{2+}$ ions at $\mathrm{A}$ sites and $\mathrm{Co}^{3+}, \mathrm{Mn}^{3+}$ and $\mathrm{Mn}^{4+}$ ions at $\mathrm{B}$ sites leading to an ionic configuration ${ }^{47}$. Table III gathers the experimental values of the lattice constant, $a_{o}$, and the global oxidizing power, $q(x)$, from which best fitted cationic distributions displayed in Table IV were established. The values for the calculated parameters $a_{0}$ and $q(x)$ on the basis of these cationic distributions are also shown in Table III.

Table III. Experimental and calculated values of the lattice constant $\mathrm{a}_{\mathrm{o}}$ and global oxidizing power $\mathrm{q}(\mathrm{x})$ of the oxides $\mathrm{Co}_{3} \mathrm{O}_{4}$ and $\mathrm{MnCo}_{2} \mathrm{O}_{4}$.

\begin{tabular}{|l|l|l|l|l|}
\hline \multirow{2}{*}{ Compound } & \multicolumn{2}{|c|}{$\mathbf{a}_{\mathbf{0}} / \mathbf{n m}$} & \multicolumn{3}{c|}{ q /eq. mol $^{-1}$} \\
\cline { 2 - 5 } & $\mathrm{a}_{\mathrm{o} \text { exp }}$ & $\mathrm{a}_{\text {o calc }}$ & $\mathrm{q}_{\text {exp }}$ & $\mathrm{q}_{\text {calc }}$ \\
\hline $\mathrm{Co}_{3} \mathrm{O}_{4}$ & 0.80788 & 0.80793 & 1.92 & 1.94 \\
\hline $\mathrm{MnCo}_{2} \mathrm{O}_{4}$ & 0.80894 & 0.80896 & 2.50 & 2.48 \\
\hline
\end{tabular}

Table IV. Cationic distributions for the oxides $\mathrm{Co}_{3} \mathrm{O}_{4}$ and $\mathrm{MnCo}_{2} \mathrm{O}_{4}$.

\begin{tabular}{|c|c|c|c|}
\hline Compound & Cationic distributions & $\mathbf{R}_{\text {Bragg }}$ & GOF \\
\hline $\mathrm{Co}_{3} \mathrm{O}_{4}$ & $\mathrm{Co}^{2+}{ }_{0.85} \mathrm{Co}^{3+}{ }_{0.15}\left[\mathrm{Co}^{3+}{ }_{1.79} \mathrm{Co}^{2+}{ }_{0.18} \square_{0.03}\right]$ & 2.056 & 1.143 \\
\hline $\mathrm{MnCo}_{2} \mathrm{O}_{4}$ & $\begin{array}{c}\mathrm{Co}^{2+}{ }_{0.88} \mathrm{Mn}^{2+}{ }_{0.12}\left[\mathrm{Co}^{3+}{ }_{0.87} \mathrm{Co}^{2+}{ }_{0.22}\right. \\
\left.\mathrm{Mn}_{0.09}^{3+} \mathrm{Mn}_{0.76}^{4+} \square_{0.06}\right]\end{array}$ & 2.161 & 1.241 \\
\hline
\end{tabular}

We are now able to propose the most probable cationic distribution of the compounds as a result of a coherent study that includes:

- $\mathrm{Co}^{\mathrm{n}+}-\mathrm{O}$ and $\mathrm{Mn}^{\mathrm{n}+}-\mathrm{O}$ distances, where $\mathrm{n}$ can be 2,3 or $4{ }^{35}$, considering cation lattice site preferences.

- similarities between the calculated global oxidizing power $q_{\text {calc }}$ values and the experimental ones $\mathrm{q}_{\text {exp }}$.

- the excellent fit between XDR results and the results obtained from the Rietveld refinement. 


\section{CONCLUSIONS}

In earlier work ${ }^{10}$, the preparation of the title compounds by spray pyrolysis at the same temperature $\left(150^{\circ} \mathrm{C}\right)$ as film electrodes was successfully undertaken by us, under rigourous preparation conditions with $\mathrm{a}_{\mathrm{o}}=0.8068$ and $\mathrm{q}(\mathrm{x})=$ 1.6 for $\mathrm{Co}_{3} \mathrm{O}_{4}$, and $\mathrm{a}=0.8197$ and $\mathrm{q}(\mathrm{x})=1.9$ for $\mathrm{MnCo}_{2} \mathrm{O}_{4}$. Following the present results on the studied oxides we have now successfully accomplished the preparation of low temperature $\mathrm{Co}_{3} \mathrm{O}_{4}$ and $\mathrm{MnCo}_{2} \mathrm{O}_{4}$ materials by thermal decomposition of nitrate precursors. The syntheses of the compounds require a thermal treatment for several days to achieve thermal equilibrium. The formation of a cubic spinel-type phase for $\mathrm{Co}_{3} \mathrm{O}_{4}$ and $\mathrm{MnCo}_{2} \mathrm{O}_{4}$ has been achieved. The spinel oxides thus prepared have a large specific surface area $\left(70 \mathrm{~m}^{2} \mathrm{~g}^{-1}\right)$ and both types are nanometric materials. The cobalt oxide showed $45 \mathrm{~nm}$ of crystallite size while manganese-cobalt oxide only $13 \mathrm{~nm}$. However when $\mathrm{MnCo}_{2} \mathrm{O}_{4}$ was prepared as a thin film using the spray pyrolysis technique at the same temperature, the crystallite was bigger ${ }^{5}(20 \mathrm{~nm})$ thus showing the effect of the preparation method.

The cationic distribution proposed on the basis of a series of physicochemical measurements show an excellent agreement with the cationic distribution obtained from the Rietveld structural analysis method of XRD data.

The preparation and the crystallographic study of the rest of the oxides family ( $\mathrm{x}=0.25$ and 0.75 ) is currently in progress. A further electrochemical characterization study will complete this work.

\section{ACKNOWLEDGEMENTS}

The authors acknowledge financial support from the DICYT-USACH (project 05-0742EVHC) and JLG thanks also CONICYT (Fondecyt 1050178).

\section{REFERENCES}

1. E. Ríos, J.L. Gautier, G. Poillerat, P. Chartier. Electrochim. Acta. 44, 1491, (1998).

2. J.L. Gautier and J. Ortiz in Electroquímica y electrocatálisis, AlonsoVante, editor, vol. 3, 2000 e-libro net.

3. F.M.M Borges, D.M.A Melo, M.S.A. Camara, A.E. Martinelli, J.M. Soares, J.H. De Araujo, F.A.O Cabral. J. Magn. Magn. Mater. 302, 273, (2006).

4. J.L Martín De Vidales, O. García, E. Vila, R.M. Rojas, M.J. Torralvo. Mat. Res. Bull. 28, 1135, (1993).

5. E. Ríos, G. Poillerat, J.F. Koenig, J.L. Gautier, P. Chartier. Thin Solid Films. 264, 18, (1995).

6. S. Trasatti. Electrochim. Acta. 36, 225, (1991).

7. B. Gillot, S. Buguet, E. Kester. J. Mater. Chem. 7 (25), 2513, (1997).

8. J.L. Gautier, E. Ríos, M. Gracia, J.F. Marco, J.R. Gancedo. Thin Solid Films 311, 51, (1997).

9. J.L. Martín De Vidales, E. Vila, R.M. Rojas, O. García. Chem. Mater. 7, 1716, (1995)

10. A. Restovic, E. Ríos, S. Barbato, J. Ortíz, J.L. Gautier. J. Electroanal. Chem. 522, 141, (2002) (and references therein).

11. D.G. Wickham, W.J. Croft. J. Phys. Chem. Solids. 7, 351, (1958).

12. S. Naka, M. Inagaki, T. Tanaka. J. Mater. Sci. 7, 441, (1972).

13. P. Cosse. J. Inorg. Nucl. Chem. 8, 483, (1958).
14. W.L Roth. J. Phys. Chem. Solids. 25, 1, (1964).

15. W. Kündig, M. Kobelt, H. Appel, G. Constabaris, H. Lindquist. J. Phys. Chem. Solids. 30, 819, (1969).

16. K. Miyatami, K. Kohn, H. Kamimura, S. Iida. J. Phys. Soc. Jpn. 21, 464, (1966).

17. H. Kamimura. J. Phys. Soc. Jpn. 21, 484, (1966).

18. O. Knop, K.I.G. Reid, Sutarno, Y. Nakagawa. Can. J. Chem. 46, 3463, (1968).

19. E. Ríos, G. Zelada, J.F. Marco, J.L. Gautier. Bol. Soc. Chil. Quim. 43, 447, (1998).

20. G. Blasse. Philips Res. Rep. Suppl. 18, 383, (1963).

21. B. Boucher, R. Buhl, R. Di Bella, M. Perrin. J. Phys. (Paris). 31, 113, (1970).

22. J.F. Marco, M. Gracia, J.R. Gancedo, J.L. Gautier, F.J. Berry. Recent Res. Devel. Inorg. Organometallic Chem. 1, 45, (2001).

23. P. Ravindranathan, G.V. Manesh, K.C. Patil. J. Sol. State Chem. 66, 20, (1987).

24. N. Yamamoto, S. Higashi, S. Kawano, N. Achiwa. J. Mater. Sci. Lett. 2 , 525, (1983)

25. J.L. Gautier, R. Fuentealba, C. Cabezas. Zeits für Phys. Chem. NF 126, 71, (1981).

26. J.L. Gautier, S. Barbato, J. Brenet. C.R. Acad. Sci. Paris, 294, 427, (1982).

27. J.L. Gautier, C. Cabezas. J. Electroanal. Chem. 159, 137, (1983).

28. E. Jabry, A. Rousset, A. Lagrange. Phase Transitions 13, 63, (1988).

29. M. El Baydi, G. Poillerat, J.L. Rehspringer, J.L. Gautier, J.F. Koenig, P. Chartier. J. Solid State Chem. 109, 281, (1994).

30. D. Pope, D.S. Walker, R.L. Moss. J. Catal. 47, 33, (1977).

31. R. Garavaglia, C.M. Mari, S. Trasatti, C. De Asmundis. Surf. Technol. 19, 197, (1983)

32. J. Rodriguez-Carvajal. ${ }^{2}$ Fullprof: a program for Rietveld refinement and pattern matching analysis ${ }^{2}$, Laboratoire Léon Brillouin CEA-CNRS, Grenoble, France, 2007.

33. E. Ríos, S. Abarca, P. Daccarett, H. Nguyen Cong, D. Martel, J.F. Marco, J.R. Gancedo, J.L. Gautier. Int. J. Hydrogen Energy 33, 4945, (2008).

34. D.A. Skoog, D.M. West, F.J. Holler. In Química Analítica, McGraw-Hill, México 1995 p. 315.

35. P. Poix. Bull. Soc. Chim. Fr. 1085, (1965).

36. R.D. Shannon, C.T. Prewitt. Acta Cryst. B25, 925, (1969).

37. A. Paul, S. Basu. Trans. J. Br. Ceram. Soc. 73, 167, (1974).

38. D.S. McClure. Phys. Chem. Solids 3, 311, (1957).

39. J.D. Dunitz, L.E. Orgel. Phys. Chem. Solids. 3, 20, (1957).

40. J.D. Dunitz, L.E. Orgel. Phys. Chem. Solids. 3, 318, (1957).

41. E. Ríos, O. Peña, T. Guizouarn, J.L. Gautier. Phys. Stat. Sol. C, 1, 108 (2004).

42. A.J.C. Wilson. X-Ray Optics, Wiley \& sons Inc. N.Y. 1962, p.113.

43. R.D. Shannon. Acta Cryst. A32, 751, (1976).

44. R.M. Rojas, E. Vila, O. García, J.L. Martín De Vidales. J. Mater. Chem. 4, 1635, (1994).

45. O.I. Gyrdasova, G.V. Bazuev, I.G. Grigorov, O.V. Koryakova. Inorg. Mater. 4, 1126, (2006).

46. E. Ríos, H. Reyes, J. Ortíz, J.L. Gautier. Electrochim. Acta. 50, 2705 , (2005).

47. E. Vila, R.M. Rojas, J.L. Martín De Vidales, O. Garcia. Chem. Mater. 8, 1078, (1996). 